\title{
Morphological and Molecular Characteristics of Kudoa viseuensis n. sp. (Myxosporea: Multivalvulida), Found in the Muscle of Batrachoides surinamensis (Teleostei: Batrachoididae) in the Brazilian Amazon Region
}

urn:Isid:zoobank.org:pub:F9D66870-38E1-440E-84CC-03E9CBF3FBCA

\section{Elideth Pacheco MONTEIRO ${ }^{1}$, Diehgo Tuloza DA SILVA ${ }^{1}$, Igor HAMOY², Osimar SANCHES ${ }^{3}$, Edilson MATOS ${ }^{1}$}

\footnotetext{
${ }^{1}$ Carlos Azevedo Research Laboratory, Institute of Animal Health and Production, Federal Rural University of Amazonia, Belém, PA, Brazil

${ }^{2}$ Laboratory of Applied Genetics, Sociambiental Institute and Water Resources, Federal Rural University of Amazonia, Belém, PA, Brazil

${ }^{3}$ Centro de Diagnóstico Veterinário (CDAPVET), Presidente Prudente, SP, Brasil and Universidade Santo Amaro - UNISA - SP
}

\begin{abstract}
A new species of myxozoan, Kudoa viseuensis n. sp. (Myxosporea: Multivalvulida), is described based on specimens extracted from the musculature of the Pacuma toadfish, Batrachoides surinamensis, collected in the municipality of Viseu, in the northern Brazilian state of Pará. A total of 60 specimens of B. surinamensis were examined, of which $52(86 \%)$ presented whitish pseudocysts containing numerous rounded spores $(7.2 \pm 0.2 \mu \mathrm{m}$ in length and $5.2 \pm 0.2 \mu \mathrm{m}$ in width). These spores have four polar capsules of equal size, measuring $1.8 \pm 0.2 \mu \mathrm{m} \times 1.3 \pm 0.1 \mu \mathrm{m}$ in the apical view, and $2.7 \pm 0.2 \mu \mathrm{m} \times 1.3 \pm 0.1 \mu \mathrm{m}$ in the lateral view. A partial sequence (1400 bps) of the small subunit ribosomal RNA gene was obtained and deposited in GenBank (access number: MK256272). The comparison of the morphological and molecular data with those of other Kudoa species supported the description of a new species of mixosporean from the Amazon region, which is denominated here as Kudoa viseuensis n. sp.
\end{abstract}

Key words: Myxozoa, molecular characterisation, morphology.

\section{INTRODUCTION}

The subphyla Myxozoa, part of the phylum Cnidaria (Hatschek, 1888), is composed of endoparasites that oc-

\footnotetext{
Address for correspondence: Edilson Rodrigues Matos, Carlos Azevedo Research Laboratory, Institute of Animal Health and Production, Federal Rural University of Amazonia, Avenida Presidente Tancredo Neves, No 2501, CEP 66.077-830, Belém, PA, Brazil; E-mail: edilson.matos9@gmail.com
}

cur in both marine and freshwater environments (Fiala et al. 2015), affecting wild and farmed fish populations. The diseases caused by these parasites can cause considerable economic losses in fishery and aquaculture operations (Okamura et al. 2015).

The myxozoan of this group often cause only innocuous infections that have little impact on the host organism (Shul'man 1990, Lom and Dyková 1992), but in some cases, they proliferate rapidly and may provoke grave epidermic lesions and epidemics (Saha and Ban- 
dyopadhyay, 2017b). In general, myxozoans infest two hosts during their life cycle, typically an intermediate vertebrate host, and a definitive invertebrate host (Okamura et al. 2015).

Marine fish are an economically important fishery resource (Rosa and Lima, 2008), and one example is the Pacuma toadfish, Batrachoides surinamensis (Bloch and Schneider, 1801), known locally as the pacamão (Espírito-Santo et al. 2005) in the Bragança region of northeastern Pará, at the eastern extreme of the Brazilian Amazon region, where it is a popular food fish in local markets (Freire et al. 2011).

The myxozoan genus Kudoa presents tropism towards the skeletal musculature, and is known to be responsible for postmortem myoliquefaction in the host (Kristmundsson and Freeman 2014), although these parasites have also been described in other types of tissue and organs, such as the intestine (Yurakhno et al. 2007), ovary (Mansour et al. 2015), oesophagus (Velasco et al. 2015b), and heart (Abdel-Ghaffar et al. 2016). The spores of this genus may be star-shaped, square or rounded quadrangular (Casal 2009), and are generally made up of four or more shell valves and polar capsules of equal number (Whipps et al. 2004).

In the Amazon region, mixosporean of the genus $\mathrm{Ku}$ doa have been found infecting the muscle of Aequidens plagionatus (Casal et al. 2008), Chaetobranchopsis orbicularis (Azevedo et al. 2016, Sindeaux Neto et al. 2017) and Plagioscion squamosissimus (Oliveira et al. 2015), while in Hypophthalmus marginatus, Velasco et al. (2015b) found this parasite in the muscle layer of the intestine. In the present study, we describe a new species, Kudoa viseuensis n. sp., which was observed infecting the musculature of $B$. surinamensis specimens collected in the municipality of Viseu, northeastern Pará.

\section{MATERIALS AND METHODS}

\section{Sampling}

A total of 60 B. surinamensis specimens (42 females and 18 males) were collected from the Gurupi River, on the eastern margin of the municipality of Viseu, Pará $\left(1^{\circ} 08^{\prime} \mathrm{S}, 46^{\circ} 05^{\prime} \mathrm{W}\right)$ between August 2016 and February 2018. The specimens were transported alive in aerated plastic bags filled with river water to the Carlos Azevedo Research Laboratory (LPCA) at the Federal Rural University of Amazonia (UFRA) in Belém, northern Brazil, where they were maintained in the same water in $20 \mathrm{~L}$ glass aquaria, at a temperature of $26-28^{\circ} \mathrm{C}, \mathrm{pH}$ of 7 , with $4.73-6.8 \mathrm{mg} / \mathrm{L}$ of dissolved oxygen, and
$15.3 \%$ salinity. The specimens had a mean length of $10.9 \mathrm{~cm}$ (range: $7.0 \mathrm{~cm}-14.0 \mathrm{~cm})$ and a mean weight of $15.6 \mathrm{~g}(6.1 \mathrm{~g}-31.5 \mathrm{~g})$.

For analysis, the specimens were anaesthetised with $50 \mathrm{~g} / \mathrm{L}$ tricaine metanosulfonate (MS-222 SIGMA), and then necropsied under a stereomicroscope for the identification of mixosporean lesions or pseudocysts on the external surface of the body, and in the gills and internal organs. The experimental procedures were approved by the UFRA Committee for Ethics in Animal Research (CEUA - UFRA 013/2014) and authorised by the Brazilian Institute for the Environment and Renewable Natural Resources, IBAMA (SISBIO / ICMBIO licence number 27119-1).

\section{Processing for histology}

Whitish pseudocysts were found in the epi- and hypo-axial musculature of the host. Small fragments $(0.5 \mathrm{~cm})$ of these pseudocysts were collected and fixed in Davidson solution (neutral buffered formalin, glacial acetic acid, 95\% ethyl alcohol, and distilled water) for 24 hours, dehydrated in an increasing alcohol series $(70 \%, 80 \%$, $90 \%$, Absolute I, II, and III), diaphanised in xylol, and then embedded in paraffin. Sections of $5 \mu \mathrm{m}$ thickness were then obtained, deparaffinised, and stained first in Haematoxylin and Eosin (HE) to facilitate the identification of the presence of pseudocysts, and then in Ziehl-Neelsen (ZN) to highlight the pseudocysts, spores, and polar capsules in contrast with the muscle fibers (Luna 1968). The parasite and the histological alterations associated with the infection were also examined by light microscopy, and photographed using a Zeiss Primo Star microscope attached by a Zeiss AxiocaCAm Erc 5 camera equipped with AxioVision LE software.

The fresh spores were also observed under a microscope equipped with differential interference contrast (DIC) and photographed. Morphometrics were obtained from 30 fresh spores, with the means and standard deviations being calculated for each parameter, presented together with the range (minimum-maximum) of values (Lom and Arthur, 1989).

\section{Processing for molecular biology}

For the DNA analysis, samples of the muscle tissue infected with spores were collected and preserved in $80 \%$ ethanol. The total DNA of these samples was extracted using a PureLink ${ }^{\circledR}$ Genomic DNA mini kit (Invitrogen, USA), following the manifacture's instructions.

The concentration of DNA in the samples was calculated in a Biodrop Duo (Biodrop) spectrophotometer. A sequence of the small subunit ribosomal DNA (SSU rDNA) was obtained by Polymerase Chain Reaction (PCR), initially using the universal Eukaryote $18 \mathrm{E}$ primer (Hillis and Dixon, 1991) with the 18R reverse primer (Whipps et al. 2003a), followed by a nested PCR with the Kudf/ Kudr primers (Whipps et al. 2003b). The PCR was run in a final volume of $25 \mu$ l, containing $1 \times$ ReddyMix PCR Master mix (Thermo Scientific, USA), $75 \mathrm{mM}$ Tris- $\mathrm{HCl}$ ( $\mathrm{pH} \mathrm{8.8),} 20 \mathrm{mM}$ of $\mathrm{KCl}$, $0.1(\mathrm{~V} / \mathrm{V})$ of Nonidet P40, $1.5 \mathrm{mM}$ of $\mathrm{MgCl}_{2}, 0.2 \mathrm{mM}$ of each nucleotide triphosphate (Thermo Scientific, USA), 10 pmol of each primer, 1.25 U of Taq DNA polymerase (Thermo Scientific, USA), and the DNA template $(10-50 \mathrm{ng} / \mu \mathrm{l})$.

The reaction was run in an Applied Biosystems Simple Amp ${ }^{\mathrm{TM}}$ thermocycler, based on the protocol for the $18 \mathrm{E}$ and $18 \mathrm{R}$ primers, that is: an initial denaturation for 5 minutes at $95^{\circ} \mathrm{C}$, followed by 35 cycles of $2 \mathrm{~min}$ at $95^{\circ} \mathrm{C}, 2 \mathrm{~min}$ at $48^{\circ} \mathrm{C}$ (annealing temperature), and 
4 min at $72^{\circ} \mathrm{C}$, with a final extension of 10 minutes at $72^{\circ} \mathrm{C}$. For the $\mathrm{Kudf} / \mathrm{Kudr}$ primers, the reaction protocol was 5 minutes at $95^{\circ} \mathrm{C}$, followed by 35 cycles of 30 seconds at $95^{\circ} \mathrm{C}, 30$ seconds at $53^{\circ} \mathrm{C}$ (annealing temperature), and 60 seconds at $72^{\circ} \mathrm{C}$, with a final extension of 10 minutes at $72^{\circ} \mathrm{C}$. The size and quality of the amplified DNA were verified by the electrophoresis of $3 \mu \mathrm{l}$ of the product in $1 \%$ agarose gel with $1 \mathrm{X}$ Tris-borate-EDTA (TBE), stained with SYBR ${ }^{\circledR}$ Safe (Invitrogen, EUA) and visualised under blue light. The PCR products were purified with PCR GFX ${ }^{\mathrm{TM}}$ DNA and a Gel Banding purification kit (GE Healthcare, UK), following the manifacture's protocol. The PCR products of the $18 \mathrm{E}$, Kudf and $18 \mathrm{R}$ primers were sequenced separately. The sequencing reactions were conducted using the Big Dye Terminator v3.1 Cycle Sequencing kit (Applied Biosystems, EUA), based on the manifacture's instructions, and run in an ABI 3100 Genetic Analyser (Applied Biosystems, EUA).

The sequences obtained by this procedure were aligned in the BioEdit software (Hall 1999) and ambiguous bases were clarified using the respective chromatograms. The sequences of the SSU rDNA gene of the myxozoan species deposited in the GenBank were aligned in Clustal X 1.8 (Thompson et al. 1997), at the default setting, to determine their phylogenetic relationships with the new species described here. High similarity scores in the Basic Local Alignment Search Tool (BLAST) were used as the criterion to select the GenBank sequences for inclusion in the analysis. The jModelTest software, version 0.1.1 (Guindon and Gascuel 2003; Posada 2008) was used to identify the best nucleotide substitution model for the dataset. Bayesian Inference was implemented in MrBayes, version 3.1.2 (Ronquist and Huelsenbeck 2003), using Markov Chain Monte Carlo searches of two simultaneous runs of four chains of $5,000,000$ generations, with every 500th tree being sampled. The first thousand trees were discarded as burn-in, and the posterior probability of each node were calculated from the remaining trees, examined initially in TreeView X (Page 1996). Genetic distances computed in PAUP* 4.0b1 (Swofford 2003) using the default p parameter for the SSU rDNA gene.

\section{RESULTS}

\section{Morphological analysis}

Whitish ovoid pseudocysts were observed in the skeletal musculature of the $B$. surinamensis specimens (Figure 1A), and when pressed between slide and coverslip, these pseudocysts released a number of spores with four piriform, symmetrical polar capsules, with slightly rounded valves lacking any projection (Figure $1 \mathrm{~B}$ and $1 \mathrm{C}$ ), typical of the genus Kudoa. It was not possible to verify the number of coils in the polar filament.

The histological sections of the muscle tissue indicated that the parasite developed intracellularly in the myofibers (Figure 2A), located centrally, and enveloped in a fine membrane that separates the mature spores from the muscle of the host. Individual infections were found when the cystic formation was observed within a single muscle fiber (Figure 2B), although multiple infections were also found, where two or more pseudocysts developed within the same fiber (Figure 2C).

Kudoa viseuensis n. sp.

ZooBank: 1sid:zoobank.org:act:AF886D76-EC954EA7-8F0D-DA2D4B956A60

Host: Batrachoides surinamensis (Bloch and Schneider, 1801).

Infection site: Pseudocysts in the somatic musculature.

Type locality: Brazil, state of Pará, municipality of Viseu $\left(1^{\circ} 08^{\prime} \mathrm{S}, 46^{\circ} 05^{\prime} \mathrm{W}\right)$.

Prevalence: $86 \%(52 / 60)$ of the examined hosts were infected.

Etymology: the specific name, viseuensis, refers to the municipality of Viseu, where the specimens were captured.

Type specimen: A glass slide with a $5 \mu$ m-thick histological section stained in Haematoxylin and Eosin, containing the spores of the new species was deposited in the Zoology Museum of the National Institute of Amazonian Research (INPA) in Manaus, Amazonas, Brazil, under catalog number CNIDARIA - INPA 038.

Description of the spores: The spores of Kudoa viseuensis $\mathrm{n}$. sp. were $7.2 \pm 0.2 \mu \mathrm{m}$ in length and $5.2 \pm 0.2$ $\mu \mathrm{m}$ in width (Figure 3). In the apical view, the polar capsules were $1.8 \pm 0.2 \mu \mathrm{m}$ in length and $1.3 \pm 0.1 \mu \mathrm{m}$ in width. When observed laterally, the mean length was $2.7 \pm 0.2 \mu \mathrm{m}$ and the width was $1.3 \pm 0.1 \mu \mathrm{m}$ (Table 1). Table 1 compares the dimensions of the spores and polar capsules (and the shape of the spores) of other Kudoa species with Kudoa viseuensis n. sp. (Cnidaria: Myxozoa: Myxosporea: Multivalvulida: Kudoidae). Kudoa viseuensis n. sp. was restricted to the skeletal musculature of the host, and was not found in any other organ of the host fish.

The morphological comparisons indicated that $\mathrm{Ku}$ doa viseuensis $\mathrm{n}$. $\mathrm{sp}$. is most similar to $K$. orbicularis (Azevedo et al. 2016) in terms of the width of the spore and the polar capsule, although other dimensions are clearly distinct from those of this species, and other Kudos species, studies previously. These findings, together with the molecular data (see below) lend support to the present description of the new species.

\section{Phylogenetic analyses}

A partial sequence of 1400 base pairs (bps) of the SSU rDNA gene was obtained from the spores of Kudoa viseuensis $\mathrm{n}$. sp., found in the musculature of $B$. suri- 


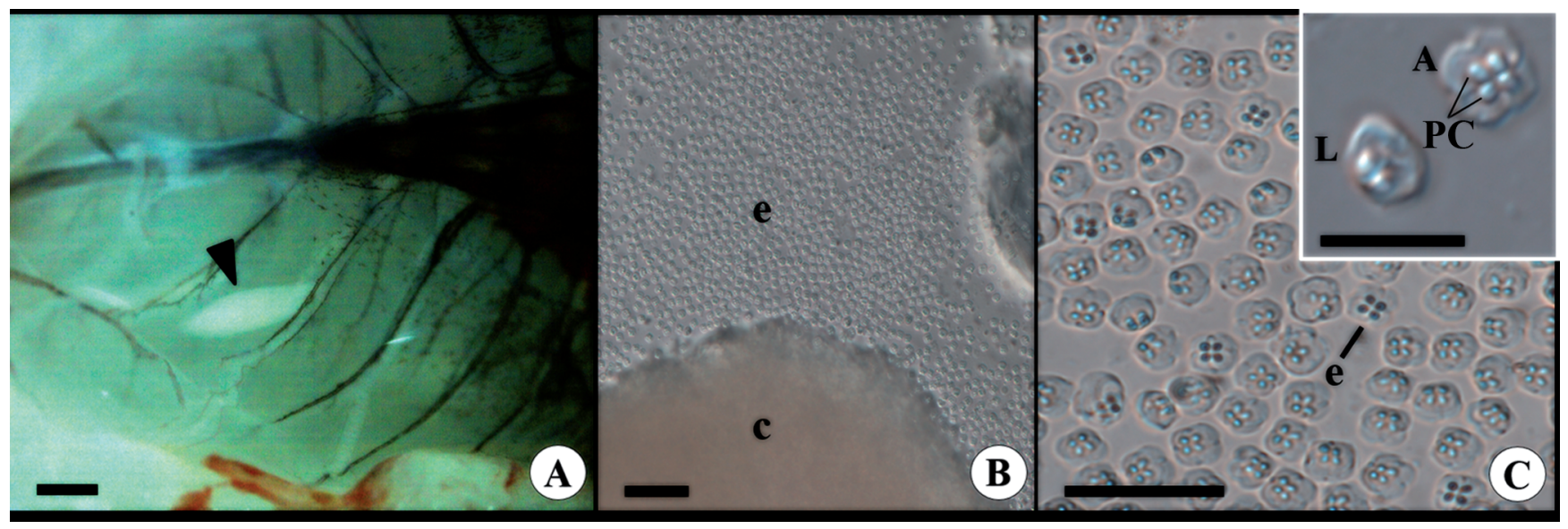

Figure 1. Light photomicrograph: (A) Whitish pseudocyst (arrowhead) found in the musculature of B. surinamensis. Scale bar: $1000 \mu$ m; (B) pseudocyst (c) and numerous mature spores (e) observed following the rupture of the pseudocyst. Scale bar: $100 \mu \mathrm{m}$; (C) Fresh, pseudo-square spores (e) of Kudoa viseuensis n. sp. Scale bar: $20 \mu \mathrm{m}$; Inset: polar capsules (PC) in lateral (L) and apical (A) views (DIC). Scale bar: $10 \mu \mathrm{m}$.

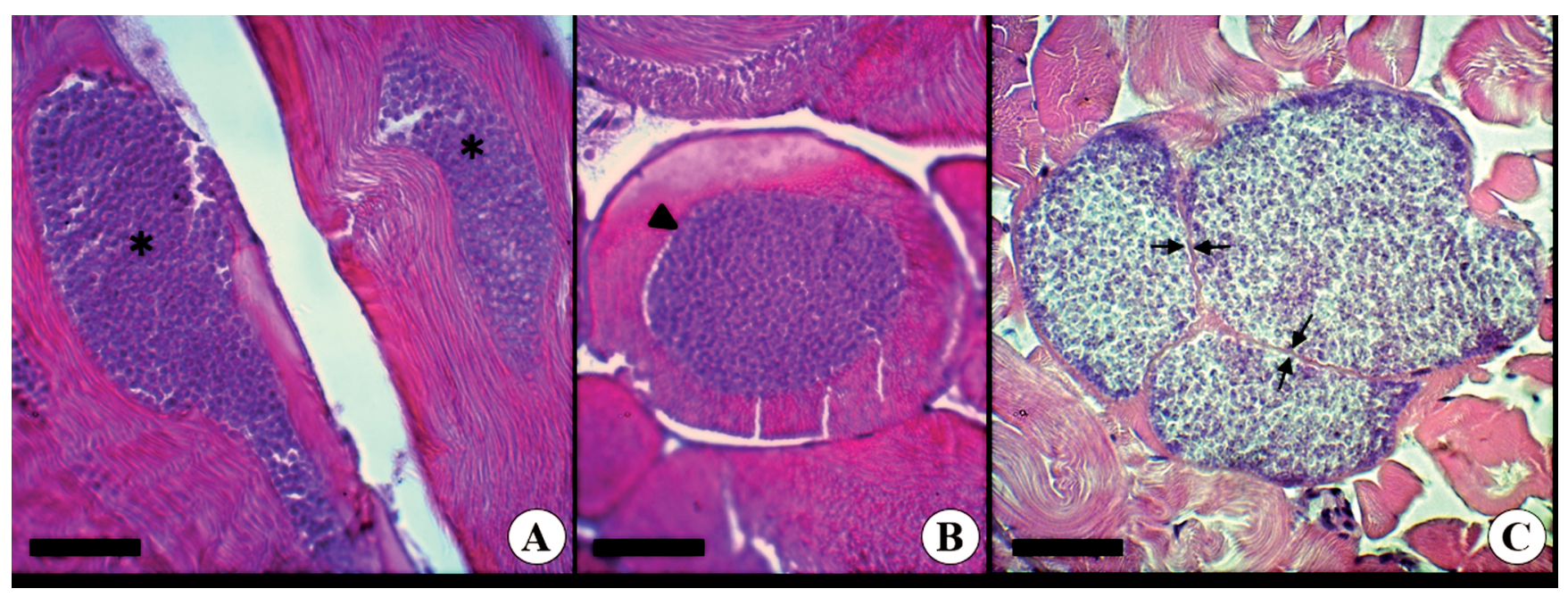

Figure 2. Light photomicrograph: (A) longitudinal histology section of the skeletal musculature of B. surinamensis containing a pseudocyst $(*)$, along the axis of the muscle, showing the substitution of the fiber by the parasite; (B) transversal section showing the pseudocyst of the mixosporean occupying the central portion of the muscle fiber (arrowhead), typical of an individual infection; (C) Multiple infection of pseudocysts within a single muscle fiber, separated from one another and the muscle tissue by a fine conjunctive membrane (arrows). Scale bars: $40 \mu \mathrm{m}$.

namensis. This sequence was deposited in GenBank under accession number MK256272. The phylogenetic tree generated by Bayesian Inference defined a major clade, denominated clade A, composed of species of the genus Kudoa (Figure 4), which is subdivided into two clades, denominated A1 and A2, with high support (posterior probabilities). Each of these clades was influenced strongly by the tissue tropism of the parasites, with Kudoa viseuensis $\mathrm{n}$. sp. being included in subclade A2. Subclade A1 is composed of Kudoa species that parasitise the musculature, brain, and intestine of fishes. Kudoa viseuensis n. sp. is included in subclade A2, which is basal to A1. Kudoa viseuensis n. sp. parasitizes the musculature of the marine fish B. surinamensis, and clusters with Kudoa orbicularis (Azevedo et al. 2016), a parasite of the musculature of the freshwater fish, Chaetobranchopsis orbicularis. In this arrangement, $K$. orbicularis is the sister species of Kudoa viseuensis n. sp., and the two species not only share the infection site, but are also found in the same geographic region. 


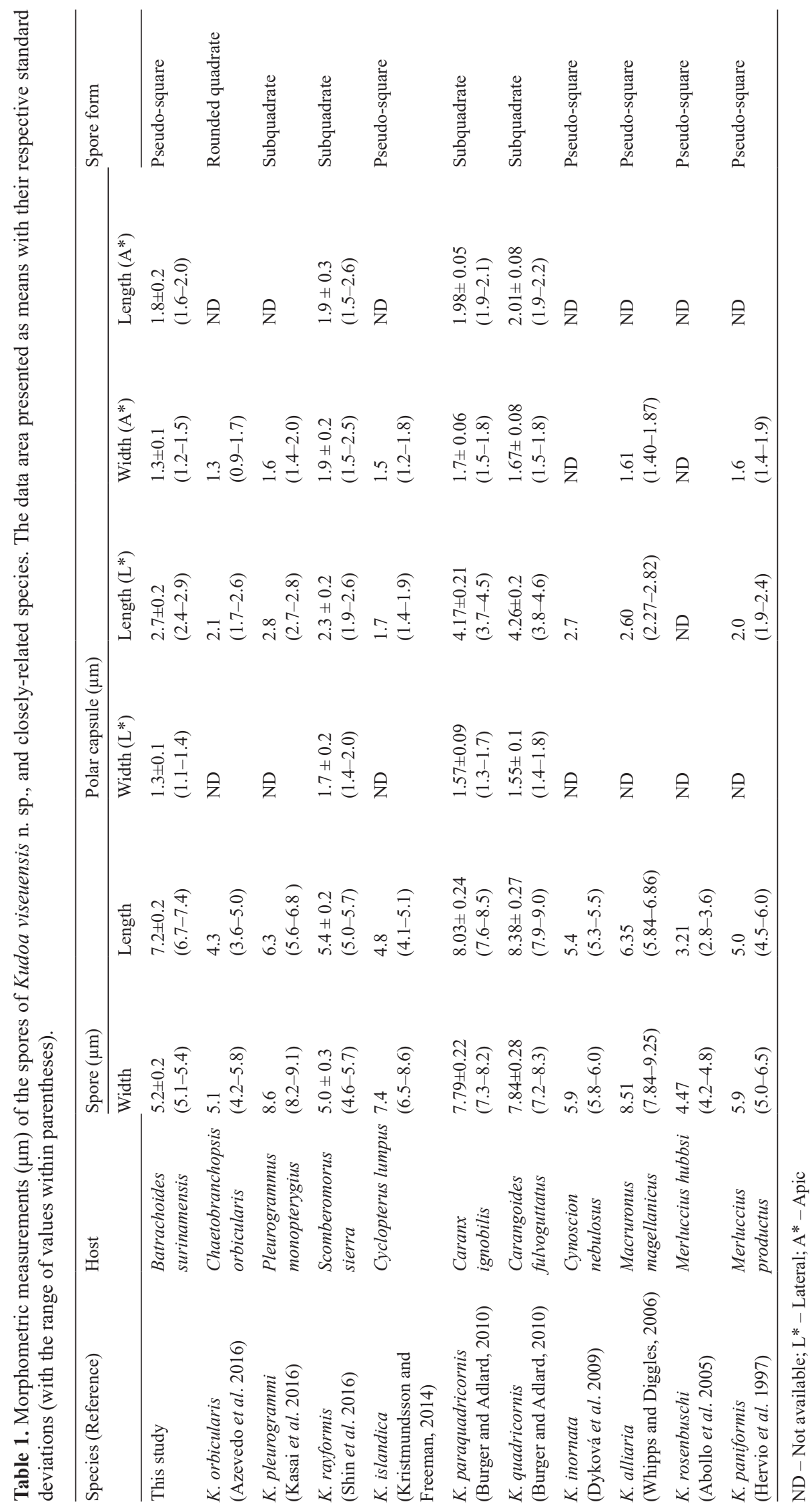



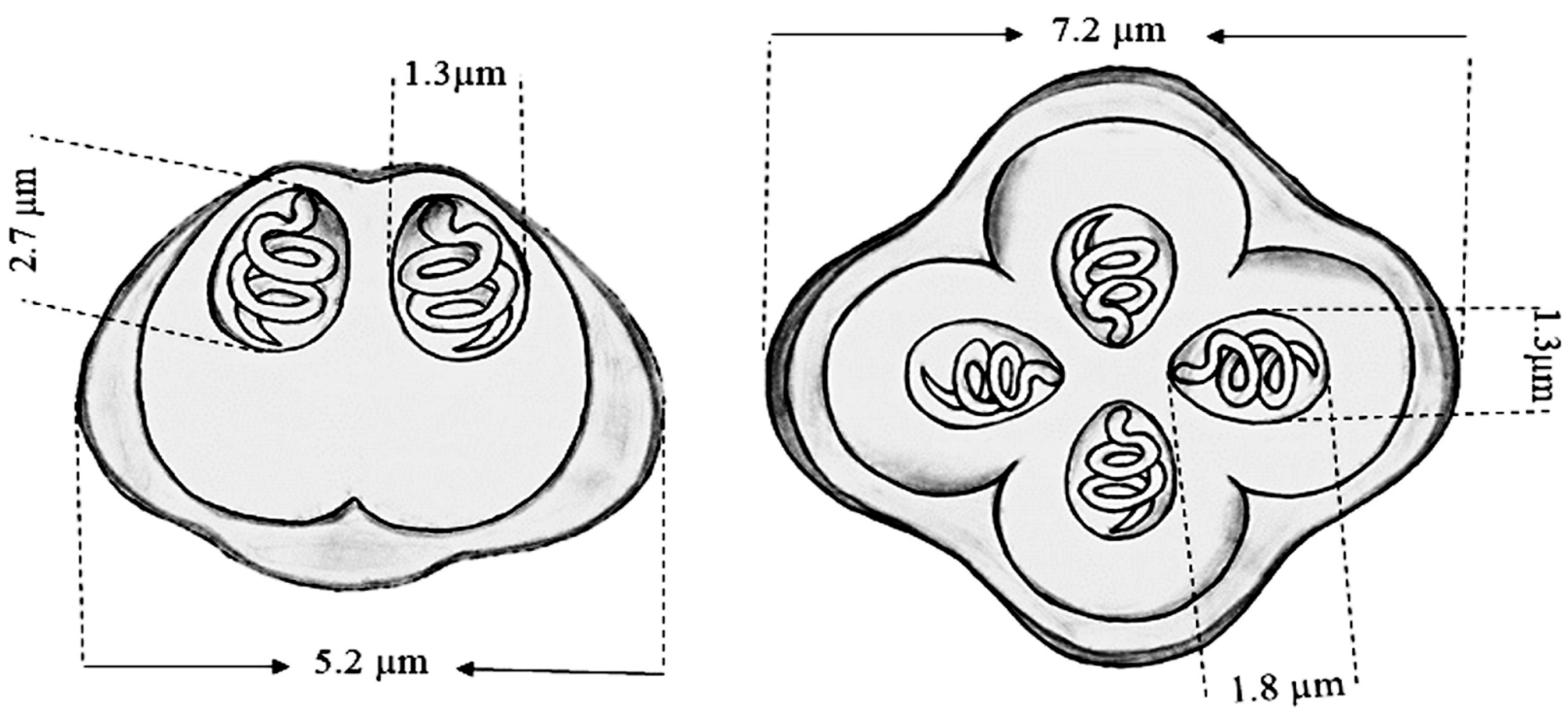

Figure 3. Schematic drawing of a spore of Kudoa viseuensis n. sp. in apical view (right) and side view (left). Scale bar $=5 \mu \mathrm{m}$

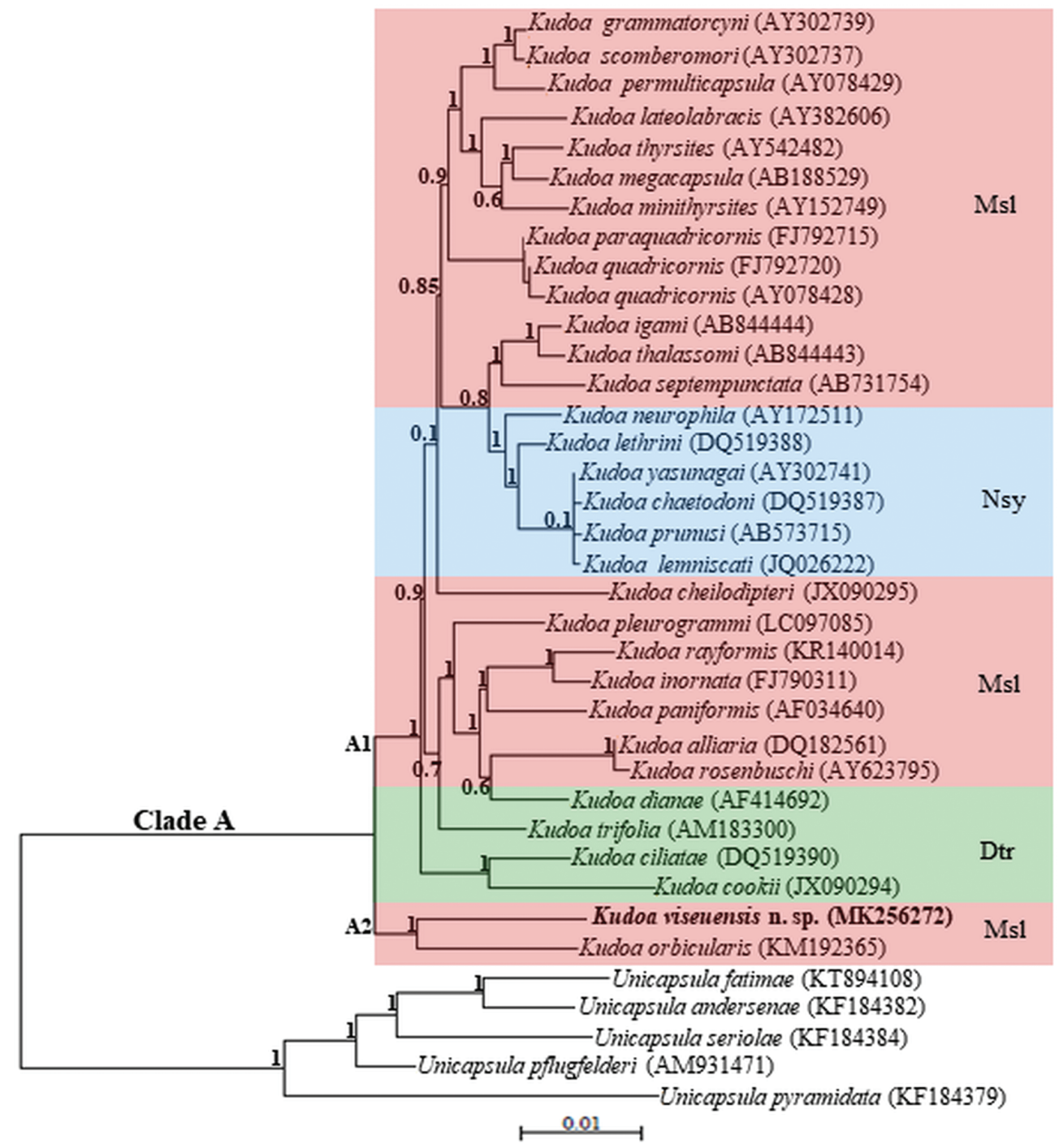

Figure 4. Phylogenetic tree derived from Bayesian Inference (BI), based on the partial sequences of the SSU rDNA gene of Kudoa viseuensis $\mathrm{n}$. sp. and closely-related myxosporans. The GenBank access numbers are shown next to the species names, and the numbers at each node are the BI posterior probabilities. The new species is highlighted in bold type. Abbreviations: Msl - muscle; Dtr - digestive tract; Nsy - nervous system. 
Table 2. Genetic distances (p) between Kudoa species that infect muscle tissue, with the respective GenBank access numbers of the samples.

\begin{tabular}{|c|c|c|c|c|c|c|c|}
\hline Species (acess number) & 1 & 2 & 3 & 4 & 5 & 6 & 7 \\
\hline $1-$ K. viseuensis $\mathrm{n} . \mathrm{sp} .(\mathrm{MK} 256272)$ & - & & & & & & \\
\hline $2-$ K. orbicularis (KM192365) & 0.0360 & - & & & & & \\
\hline $3-$ K. pleurogrammi $(\mathrm{LC} 097085)$ & 0.0360 & 0.0360 & - & & & & \\
\hline $4-$ K. paraquadricornis (FJ792715) & 0.0360 & 0.0382 & 0.0211 & - & & & \\
\hline $5-$ K. quadricornis (AY078428) & 0.0382 & 0.0405 & 0.0234 & 0.0022 & - & & \\
\hline $6-$ K. rayformis (KR140014) & 0.0420 & 0.0390 & 0.0271 & 0.0315 & 0.0338 & - & \\
\hline $7-$ K. inornata (FJ790311) & 0.0420 & 0.0427 & 0.0241 & 0.0278 & 0.0300 & 0.0116 & - \\
\hline $8-$ K. rosenbuschi (AY623795) & 0.0495 & 0.0480 & 0.0293 & 0.0352 & 0.0375 & 0.0352 & 0.0315 \\
\hline
\end{tabular}

The outgroup is composed of species of the genus Unicapsula Davis, 1924, a member of the order Multivalvulida Schulman, 1959, which infects the musculature of its hosts.

A new alignment was run for the pairwise comparison of key Kudoa species with Kudoa viseuensis n. sp. (Table 2). The smallest pairwise genetic distance (p) found in this analysis between Kudoa viseuensis n. sp. and the other Kudoa species was 3.9\% in the case of $K$. orbicularis (KM192365), while the greatest distance was $4.9 \%$ for $K$. rosenbuschi (AY623795).

\section{DISCUSSION}

All the analyses presented here support the description of Kudoa viseuensis n. sp. as a distinct new taxon of the genus Kudoa. The new parasite is clearly aligned with other Kudoa species, although this is the first kudoid species from a Brazilian estuary for which molecular data have been obtained. Infection by this new parasite is characterised by the formation of a pseudocyst in the musculature of its host (Yokoyama et al. 2012; Kasai et al. 2016, Kasai et al. 2017; Sakai et al. 2018). The infection of Kudoa species presents muscle tissue tropism, as observed in the present study, with Kudoa viseuensis $\mathrm{n}$. sp. being found only in the skeletal muscle of $B$. surinamensis, with no infection being found in any other organ, a scenario also found in the Pacific barrelfish, Hyperoglyphe japonica, in which infection by Kudoa ogawai was also limited to the muscle tissue (Yokoyama et al. 2012).

In some cases, the pseudocysts are relatively easy to detect, as in the case of Kudoa trachuri, found in the musculature of the Japanese horse mackerel, Trachurus japonicus, and Kudoa thunni in that of the albacore, Thunnus alalunga (Matsukane et al. 2011). AbdelGhaffar et al. (2016) also observed macrocsopic pseudocysts of Kudoa pagrusi in the heart muscle of the sea bream, Pagrus pagrus. In most cases, however, the infection is subclinical, and the pseudocysts are indiscernible to the naked eye, which means that the infected fish may be consumed by humans who are unable to perceive the presence of the spores (Yokoyama and Itoh 2005, Whipps and Kent 2006, Schmidt-Posthaus et al. 2012). In the present study, the pseudocysts in the skeletal muscle of $B$. surinamensis were not immediately visible, but were discovered under light microscopy, as observed by Shirakashi et al. (2014) in the Japanese parrotfish, Calotomus japonicus.

The pseudo-square spores of Kudoa viseuensis $\mathrm{n}$. sp. are distinctly smaller than those of Kudoa pleurogrammi, Kudoa paraquadricornis, Kudoa quadricornis, and Kudoa alliaria (Whipps and Diggles 2006, Burger and Adlard 2010, Kasai et al. 2016), even though the spores of some other species, such as K. orbicularis and Kudoa rayformis (Azevedo et al. 2016, Shin et al. 2016) are more similar in size. The new species has larger spores than those of $K$. rosenbuschi (Abollo et al. 2005).

The prevalence of the new species of parasite was $86 \%$, a rate lower than those recorded in the silver 
croaker, Plagioscion squamosissimus, in which $100 \%$ of the specimens analysed by Oliveira et al. (2015) were infected, or the spotted seatrout, Cynoscion nebulosus, in which $91 \%$ of the specimens examined by Dyková et al. (2009) were infected with Kudoa inornata.

Histological analyses have revealed that a large proportion of the musculature may be replaced by Kudoa pseudocysts, forming a ring around the fish (Moran et al. 1999b, Kristmundsson and Freeman 2014). Multiple infections in a single muscle fiber have also been described by Lom et al. (1983) and Moran et al. (1999c). In the present study, while localised pathological alterations were found, no clear impact on the physiology or behaviour of the host fish was detected. The response of the host varies considerably among different Kudoa species, including substantial infiltration of the inflamed cells and the formation of granulomas, although in many other cases, no response is observed in the host (Whitaker et al. 1996, Casal et al. 2008, Dyková et al. 2009).

Some kudoid species are important pathogenic agents in fisheries and aquaculture, due to the pathology caused in the host. Kudoa yasunagai, for example, infects the brain of its host, causing deformations of the vertebral column. Kudoa thyrsites (Whipps and Kent, 2006) and Kudoa lateolabracis (Yokoyama et al. 2004) cause extensive postmortem necrosis of the host, inducing the degradation of the infected tissue. $\mathrm{Ku}$ doa amamiensis (Burger et al. 2008) and K. islandica (Kristmundsson and Freeman, 2014) cause nonspecific pseudocysts in fish fillets. Kudoa septempunctata causes food poisoning (Kawai et al. 2012). These pathologies are responsible for serious economic losses in the fishery industry (Davies et al. 1998, Whipps et al. 2003a, Hadfield 2014).

The molecular analysis of sequences of the SSU rDNA gene provides important complementary evidence for the interpretation of the diversity of myxozoans. Although the morphology of the spores is essential for the taxonomic classification of species, the phenotypic similarities among kudoid species and the intraspecific variation found in many cases hampers the reliable diagnosis of species based solely on morphology (Urawa et al. 2009, Burger and Adlard 2010, Heiniger and Adlard 2012, Heiniger et al. 2013). Phylogenetic analyses have provided a better understanding of the diversity and biogeographic relationships among these parasites and their hosts (Urawa et al. 2011, Kasai et al. 2017, Sakai et al. 2018).

In the phylogenetic analysis of the myxosporeans, tissue tropism is evident in the kudoids (Fiala 2006).
The phylogenetic analysis of the partial SSU rDNA sequences produced by the Bayesian Inference (BI) revealed a close relationship between the Kudoa species that infect musculature and those that infect the nervous system, such as Kudoa neurophila (Grossel et al. 2005), Kudoa yasunagai (Whipps et al. 2004), Kudoa prunusi (Meng et al. 2011), Kudoa lemniscati (Miller and Adlard, 2012), Kudoa chaetodoni, and Kudoa lethrini (Burger et al. 2007), and those that infect the digestive tract, such as Kudoa trifolia (Holzer et al. 2006), Kudoa ciliatae (Burger et al. 2007), Kudoa cookii (Heiniger et al. 2013), and Kudoa dianae (Dyková et al. 2002). However, the Kudoa species that infect only the skeletal musculature form a group distinct from the principal Kudoa clades.

The results of the present study support the potential relationship between the biogeographic and morphological similarities of the different Kudoa species. In particular, $K$. orbicularis, which is phylogenetically closest to Kudoa viseuensis n. sp., not only infects the same type of tissue, but also occurs in the same geographic region, being found in the Amazon basin.

\section{REFERENCES}

Abdel-Ghaffar F, Abdel-Gaber R, Maher S, Al-Quraishy S, Mehlhorn H (2016) Morphological re-description and molecular characterization of Kudoa pagrusi (Myxosporea: Multivalvulida) infecting the heart muscles of the common sea bream fish Pagrus pagrus (Perciformes: Sparidae) from the Red Sea, Egypt. Parasitol Res. 15: 3175-3184

Abollo E, Novoa B, Figueras A (2005) SSU rDNA analysis of $\mathrm{Ku}$ doa rosenbuschi (Myxosporea) from the Argentinean hake Merluccius hubbsi. Dis Aquat Organ. 64: 135-139

Azevedo C, Rocha S, Matos E, Oliveira E, Matos P, Al-Quraishy S, Casal G (2016) Ultrastructural and Phylogenetic Description of Kudoa orbicularis n. sp. (Myxosporea: Multivalvulida): A Parasite Infecting the Muscle of the Fish Chaetobranchopsis orbicularis (Teleostei: Cichlidae) in the Amazon Region. J Eukaryot Microbiol. 63: 27-36

Barletta-Bergan A, Barletta M, Saint-Paul U (2002) Structure and Seasonal Dynamics of Larval Fish in the Caeté River Estuary in North Brazil. Estuar Coast Shelf Sci. 54: 193-206

Burger MA, Cribb TH, Adlard RD (2007) Patterns of relatedness in the Kudoidae with descriptions of Kudoa chaetodoni n. sp. and K. lethrini n. sp. (Myxosporea: Multivalvulida). Parasitol. 134: $669-81$

Burger MA, Barnes AC, Adlard RD (2008) Wildlife as reservoirs for parasites infecting commercial species: host specificity and a redescription of Kudoa amamiensis from teleost fish in Australia. J Fish Dis. 31: 835-44

Burger MA, Adlard RD (2010) Four new species of Kudoa Meglitsch, 1947 (Myxosporea: Multivalvulida) from Australia with recommendations for species descriptions in the Kudoidae. Parasitol. 137: 793-814

Casal G, Matos E, Matos P, Azevedo C (2008) Ultrastructural description of a new myxosporean parasite Kudoa aequidens sp. 
n. (Myxozoa, Myxosporea) found in the sub-opercular musculature of Aequidens plagiozonatus (Teleostei)from the Amazon River. Acta Protozool. 47: 135-141

Casal GMF (2009) Microsporidioses e Mixosporidioses da Ictiofauna Portuguesa e Brasileira: Caracterização Ultrastrutural e Filogenética. Tese (Doutorado em Ciências Biomédicas). Instituto de Ciências Biomédicas Abel Salazar, Universidade do Porto. Portugal

Davies AJ, Andrews T, Upton NPD, Matthews RA (1998) Kudoa as a contributory cause of muscle necrosis in gobies. Bull Eur Assoc Fish Pathol. 18: 62-66

Dyková I, Fajer Avila EJ, Fiala I (2002) Kudoa dianae sp. n. (Myxosporea: Multivalvulida), a new parasite of bullseye puffer, Sphoeroides annulatus (Tetraodontiformes: Tetraodontidae). Folia Parasitol. 49: 17-23

Dyková I, Buron I, Fiala I, Roumillat WA (2009) Kudoa inornata sp. n. (Myxosporea: Multivalvulida) from the skeletal muscles of Cynoscion nebulosus (Teleostei: Sciaenidae). Folia Parasitol. 56: $91-98$

Espírito-Santo RV, Isaac VJ, Silva LMA, Martinelli JM, Higuchi H, Paul US (2005) Peixes e camarões do litoral bragantino, Pará, Brasil. Belém: Madam. 1: 1-268

Fiala I (2006) The phylogeny of Myxosporea (Myxozoa) based on small subunit ribosomal RNA gene analysis. Int J Parasitol. 36: $1521-1534$

Fiala I, Bartošová-Sojková P, Whipps CM (2015) Classification and Phylogenetics of Myxozoa. In: Myxozoan Evolution, Ecology and Development. Springer International Publishing Switzerland. 5: $85-110$

Freire JL, Silva BB, Souza AS (2011) Aspectos Econômicos e Higiênico-Sanitários da Comercialização do Pescado no $\mathrm{Mu}-$ nicípio de Bragança (PA). Biota Amazônia. 1: 17-28.

Grossel G, Handlinger J, Battaglene S, Munday B (2005) Diagnostic polymerase chain reaction assay to detect Kudoa neurophila (Myxozoa: Multivalvulida) in a marine finfish hatchery. Dis Aquat Organ. 64: 141-149

Guindon S, Gascuel O (2003) A simple, fast, and accurate algorithm to estimate large phylogenies by maximum likelihood. Syst Biol. 52: 696-704

Hadfield CA, Poynton SL, Clayton LA, Romero JL, Montali RJ (2014) Kudoa sp. (Myxozoa: multivalvulida) in skeletal muscle of captive bullnose eagle rays, Myliobatis freminvillei (Rajiformes: Myliobatidae). J Zoo Wildl Med. 45: 896-905

Hall TA (1999) BioEdit: a user-friendly biological sequence alignment editor and analysis program for windows 95/98/NT. Nucleic Acids Symp Ser. 41: 95-98

Heiniger H, Adlard RD (2012) Host specificity and local dynamics of Kudoa leptacanthae n. sp. (Multivalvulida: Kudoidae) from the pericardial cavity of two Zoramia spp. (Perciformes: Apogonidae) at Lizard Island lagoon, Queensland, Australia. Parasitol Int. 61: 697-706

Heiniger H, Cribb TH, Adlard RD (2013) Intra-specific variation of Kudoa spp. (Myxosporea: Multivalvulida) from apogonid fishes (Perciformes), including the description of two new species, $K$. cheilodipteri n. sp. and $K$. cookii n. sp., from Australian waters. Syst Parasitol. 84: 193-215

Hervio DML, Khattra J, Devlin RH, Kent ML, Sakanari J, Yokoyama H (1997) Taxonomy of Kudoa species (Myxosporea), using a small-subunit ribosomal DNA sequence. Can J Zool. 75: 2112-2119

Hillis DM, Dixon MT (1991) Ribosomal DNA: Molecular evolution and phylogenetic inference. $Q$ Rev Biol. 66: 411-453
Holzer AS, Blasco-Costa I, Sarabeev VL, Ovcharenko MO, Balbuena JA (2006) Kudoa trifolia sp. n. - molecular phylogeny suggests a new spore morphology and unusual tissue location for a well-known genus. J Fish Dis. 29: 743-55

Kasai A, Li Y, Mafie E, Sato H (2016) Morphological and molecular genetic characterization of two Kudoa spp., K. musculoliquefaciens, and $K$. pleurogrammi n. sp. (Myxosporea: Multivalvulida), causing myoliquefaction of commercial marine fish. Parasitol Res. 115: 1883-1892

Kasai A, Setsuda A, Sato H (2017) Morphological and genetic characterization of Kudoa whippsi (Myxosporea: Multivalvulida) from Cheilodactylus zonatus in the western Pacific Ocean off Japan, and two new Kudoa spp. (K. akihitoi n. sp. and K. empressmichikoae n. sp.) from Acanthogobius hasta in the Sea of Ariake, Japan. Parasitol Res. 116: 647-659

Kawai T, Sekizuka T, Yahata Y, Kuroda M, Kumeda Y, Iijima Y, Kamata Y, Sugita-Konishi Y, Ohnishi T (2012) Identification of Kudoa septempunctata as the Causative Agent of Novel Food Poisoning Outbreaks in Japan by Consumption of Paralichthys olivaceus in Raw Fish. Clin Infect Dis. 54: 1046-1052

Kristmundsson Á, Freeman MA (2014) Negative effects of Kudoa islandica $\mathrm{n}$. sp. (Myxosporea: Kudoidae) on aquaculture and wild fisheries in Iceland. Int J Parasitol Parasites Wildl. 3: 135-146

Lom J, Dyková I, Lhotáková S (1983) Kudoa lunata n. sp. (Myxozoa, Myxosporea) and notes on the nature of muscular "cysts" of the genus Kudoa. Arch Protistenk. 127: 387-397

Lom J, Arthur JR (1989) A guideline for the preparation of species descriptions in Myxosporea. J Fish Dis. 12: 151-156

Lom J, Dyková I (1992) Protozoan Parasites of Fishes. Elsevier Science. 26: $315 \mathrm{p}$

Luna LG (1968) Manual of Histologic Staining Methods of the Armed Forces Institute of Pathology. MacGraw-Hill Book Company. $3^{\mathrm{a} e d .}$ New York

Mansour L, Harrath AH, Abdel-Baki AAS, Al-Quraishy SS, Al Omar SY (2015) Kudoa saudiensis sp. n. (Myxosporea: Multivalvulida) infecting oocytes of the Indian mackerel Rastrelliger kanagurta (Perciformes: Scombridae). Folia Parasitol. 62: $1-10$

Matsukane Y, Sato H, Tanaka S, Kamata Y, Sugita-Konishi Y (2011) Kudoa iwatai and two novel Kudoa spp., K. trachuri n. sp. and $K$. thunni n. sp. (Myxosporea: Multivalvulida), from daily consumed marine fish in western Japan. Parasitol Res. 108: 913-26

Meng F, Yokoyama H, Shirakashi S, Grabner D, Ogawa K, Ishimaru K, Sawada Y, Murata O (2011) Kudoa prunusi n. sp. (Myxozoa: Multivalvulida) from the brain of Pacific bluefin tuna Thunnus orientalis (Temminck \& Schlegel, 1844) cultured in Japan. Parasitol Int. 60: 90-96

Miller TL, Adlard RD (2012) Brain infecting kudoids of Australia's coral reefs, including a description of Kudoa lemniscati n. sp. (Myxosporea: Kudoidae) from Lutjanus lemniscatus (Perciformes: Lutjanidae) off Ningaloo Reef, Western Australia. Parasitol Int. 61: 333-42

Molnár K, Eszterbauer E, Szckely C, Dán Á, Harrach B (2002) Morphological and molecular biological studies on intramuscular Myxobolus spp. of cyprinid fish. J Fish Dis. 25: 643-652

Moran JDW, Whitaker DJ, Kent ML (1999b) Natural and laboratory transmission of the marine myxosporean parasite Kudoa thyrsites (Gilchrist, 1924) to Atlantic salmon. J Aquat Anim Health. 11: $110-115$

Moran JDW, Margolis L, Webster JM, Kent ML (1999c) Development of Kudoa thyrsites (Myxozoa: Myxosporea) in netpen- 
reared Atlantic salmon determined by light microscopy and a polymerase chain reaction. Dis Aquat Organ. 37: 185-193

Okamura B, Gruhl A, Reft AJ (2015) Myxozoan Evolution, Ecology and Development. Springer International Publishing.

Oliveira JC, Velasco M, Santos PFS, Silva JMV, Clemente SCS, Matos E (2015) Kudoa spp. (Myxozoa) infection in musculature of Plagioscion squamosissimus (Sciaenidae) in the Amazon region, Brazil. Rev Bras Parasitol Vet. 24: 235-240

Page RDM (1996) TREEVIEW: an application to display phylogenetic trees on personal computers. Comput Appl Biosci. 12: $357-358$

Posada D (2008) jModelTest: phylogenetic model averaging. Mol Biol Evol. 25: 1253-1256

Ronquist F, Huelsenbeck JP (2003) MRBAYES 3: Bayesian phylogenetic inference under mixed models. Bioinformatics. 19: 1572-1574

Rosa RS, Lima FCT (2008) Os peixes brasileiros ameaçados de extinção. In: Livro vermelho das espécies ameaçadas de extinção. Brasília

Saha M, Bandyopadhyay PK (2017b) Studies on histopathological alteration of three major organs of the goldfish, Carassius auratus L., of India due to myxozoan infestation with special reference to scanning electron microscopic observation. Parasitol Res. 116: 511-520

Sakai H, Kato E, Sakaguchi S, Setsuda A, Sato H (2018) Morphological and molecular genetic characterization of Kudoa konishiae n. sp. (Myxosporea: Multivalvulida) in the muscle of Japanese Spanish mackerel (Scomberomorus niphonius). Parasitol Res. 117: 893-904

Schmidt-Posthaus H, Bettge K, Forster U, Segner H, Wahli T (2012) Kidney pathology and parasite intensity in rainbow trout $\mathrm{On}$ corhynchus mykiss surviving proliferative kidney disease: time course and influence of temperature. Dis Aquat Organ. 97: 207-218

Shin SP, Shirakashi S, Hamano S, Kato K, Lasso LT, Yokoyama H (2016) Phylogenetic study of the genus Kudoa (Myxozoa: Multivalvulida) with a description of Kudoa rayformis sp. nov. from the trunk muscle of Pacific sierra Scomberomorus sierra. Mol Phylogenet Evol. 98: 337-345

Shirakashi S, Yamane K, Ishitani H, Yanagida T, Yokoyama H (2014) First report of Kudoa species in the somatic muscle of the Japanese parrotfish Calotomus japonicus (Scaridae) and a description of Kudoa igami, n. sp. (Myxozoa: Multivalvulida). Parasitol Res. 113: 2515-2524

Shul'man SS (1990) Myxosporidia of the USSR. Russian Translations Series 75. A.A. Balkema/Rotterdam. p. 631

Sindeaux Neto JL, Velasco M, Santos P, Matos P, Matos E (2017) Infection of the muscle tissue of the filter-feeding cichlid, Chaetobranchopsis orbicularis Steindachner, 1875, by Kudoa orbicularis (Myxozoa: Multivalvulidae) on Marajó Island in the Brazilian Amazon region. Arq Bras Med Vet Zootec. 9: 1601-1606

Swofford DL (2003) PAUP*. Phylogenetic analysis using parsimony (*and other methods) Sinauer associates, Sunderland. v. 4.0 beta 10

Thompson JD, Gibson TJ, Plewniak F, Jeanmougin F, Higgins DG (1997) The CLUSTAL-X window interface: flexible strategies for multiple sequence alignment aided by quality analysis tools. Nucl Acids Res. 25: 4876-4882
Urawa S, Iida Y, Freeman MA, Yanagida T, Karlsbakk E, Yokoyama H (2009) Morphological and molecular comparisons of Myxobolus spp. in the nerve tissues of salmonid fishes with the description of Myxobolus murakamii n. sp., the causative agent of myxosporean sleeping disease. Fish Pathol. 44: 72-80

Urawa S, Freeman MA, Johnson SC, Jones SR, Yokoyama H (2011) Geographical variation in spore morphology, gene sequences, and host specificity of Myxobolus arcticus (Myxozoa) infecting salmonid nerve tissues. Dis Aquat Organ. 96: 229-237

Velasco M, Videira M, Silva JMV, Sanches O, Matos PS, São Clemente SC, Matos E (2015b) Esophageal infection due to Kudoa sp. (Myxozoa) in mapara catfish, Hypophthalmus marginatus. Aquacul Reports. 2: 22-25

Whipps CM, Adlard RD, Bryant MS, Kent ML (2003a) Two unusual myxozoans, Kudoa quadricornis n. sp. (Multivalvulida) from the muscle of goldspotted trevally (Carangoides fulvoguttatus) and Kudoa permulticapsula n. sp. (Multivalvulida) from the muscle of Spanish mackerel (Scomberomorus commerson) from the Great Barrier Reef, Australia. J Parasitol. 89: 168-173

Whipps CM, Adlard RD, Bryant MS, Lester RJ, Findlay V, Kent ML (2003b) First Report of Three Kudoa Species from Eastern Australia: Kudoa thyrsites from Mahi mahi (Coryphaena hippurus), Kudoa amamiensis and Kudoa minithyrsites n. sp. from Sweeper (Pempheris ypsilychnus). J Eukaryot Microbiol. 50: 215-219

Whipps CM, Grossel G, Adlard RD, Yokoyama H, Bryant MS, Munday BL, Kent ML (2004) Phylogeny of the Multivalvulidae (Myxozoa: Myxosporea) based on comparative ribosomal DNA sequence analysis. J Parasitol. 90: 618-622

Whipps CM, Diggles BK (2006) Kudoa alliaria in flesh of Argentinian hoki Macruronus magellanicus (Gadiformes; Merlucciidae). Dis Aquat Organ. 69: 259-263

Whipps CM, Kent ML (2006) Phylogeography of the Cosmopolitan Marine Parasite Kudoa thyrsites (Myxozoa: Myxosporea). $J$ Eukaryot Microbiol. 53: 364-373

Whitaker DJ, Kent ML, Sakanari JA (1996) Kudoa miniauriculata n. sp. (Myxozoa, Myxosporea) from the musculature of bocaccio (Sebastes paucispinis) form California. J Parasitol. 82: 312-315

Yokoyama H, Whipps CM, Kent ML, Mizuno K, Kawakami H (2004) Kudoa thyrsites from Japanese Flounder and Kudoa lateolabracis n. sp. from Chinese Sea Bass: Causative Myxozoans of Post-Mortem Myoliquefaction. Pathology. 39: 79-85

Yokoyama H, Itoh N (2005) Two Multivalvulid Myxozoans Causing Postmortem Myoliquefaction: Kudoa megacapsula n. sp. from red barracuda (Sphyraena pinguis) and Kudoa thyrsites from splendid alfonso (Beryx splendens). J Parasitol. 91: 1132-1137

Yokoyama H, Yanagida T, Shirakashi S (2012) Kudoa ogawai n. sp. (Myxozoa: Multivalvulida) from the trunk muscle of Pacific barrel fish Hyperoglyphe japonica (Teleostei: Centrolophidae) in Japan. Parasitol Res. 110: 2247-2254

Yurakhno VM, Ovcharenko MO, Holzer AS, Sarabeev VL, Balbuena JA (2007) Kudoa unicapsula n. sp. (Myxosporea: Kudoidae) a parasite of the Mediterranean mullets Liza ramada and L. aurata (Teleostei: Mugilidae). Parasitol Res. 101: 1671-80

Received on $15^{\text {th }}$ January, 2019; revised on $13^{\text {th }}$ March, 2019; accepted on $24^{\text {th }}$ June, 2019 